\title{
Pro-apoptotic kinase levels in cerebrospinal fluid as potential future biomarkers in Alzheimer's disease
}

\author{
Claire Paquet*, Julien Dumurgier and Jacques Hugon \\ INSERM UMR-S942, Centre Mémoire de Ressources et de Recherche (CMRR) Paris Nord lle de France, Groupe Hospitalier \\ Lariboisière Fernand-Widal Saint-Louis, AP-HP, Université Paris Diderot, Paris, France
}

OPEN ACCESS

Edited by:

Charlotte Elisabeth Teunissen, VU University Medical Center Amsterdam, Netherlands

Reviewed by: Jesus Avila Centro de Biología Molecular Severo Ochoa, Spain Andrea F. N. Rosenberger, VU University Medical Center Amsterdam, Netherlands

${ }^{*}$ Correspondence: Claire Paquet,

INSERM UMR-S942, Centre Mémoire de Ressources et de Recherche (CMRR) Paris Nord lle de France,

Groupe Hospitalier Lariboisière Fernand-Widal Saint Louis, 200 Rue du Faubourg Saint Denis,

Paris 75010, France claire.paquet@inserm.fr

Specialty section: This article was submitted to Neurodegeneration, a section of the

journal Frontiers in Neurology

Received: 12 May 2015 Accepted: 20 July 2015 Published: 04 August 2015

Citation:

Paquet $C$, Dumurgier $J$ and Hugon $J$ (2015) Pro-apoptotic kinase levels in cerebrospinal fluid as potential future biomarkers in Alzheimer's disease. Front. Neurol. 6:168. doi: 10.3389/fneur.2015.00168
Alzheimer's disease $(A D)$ is characterized by the accumulation of $A \beta$ peptides, hyperphosphorylated tau proteins, and neuronal loss in the brain of affected patients. The causes of neurodegeneration in $A D$ are not clear, but apoptosis could be one of the cell death mechanisms. According to the amyloid hypothesis, abnormal aggregation of $A \beta$ leads to altered kinase activities inducing tau phosphorylation and neuronal degeneration. Several studies have shown that pro-apoptotic kinases could be a link between $A \beta$ and tau anomalies. Here, we present recent evidences from AD experimental models and human studies that three pro-apoptotic kinases (double-stranded RNA kinase (PKR), glycogen synthase kinase-3 $\beta$, and C-Jun terminal kinase (JNK) could be implicated in AD physiopathology. These kinases are detectable in human fluids and the analysis of their levels could be used as potential surrogate markers to evaluate cell death and clinical prognosis. In addition to current biomarkers ( $A \beta_{1-42}$, tau, and phosphorylated tau), these new evaluations could bring about valuable information on potential innovative therapeutic targets to alter the clinical evolution.

Keywords: cerebrospinal fluid, pro-apoptotic kinase, PKR, GSK-3, JNK, Alzheimer's disease

\section{Introduction}

Neuropathological lesions in Alzheimer's disease (AD) include senile plaques, neurofibrillary tangles, and amyloid angiopathy leading to synaptic and neuronal degradations. $A \beta$ is formed after the cleavage of amyloid precursor protein (APP) by $\beta$ secretase (BACE1) and $\gamma$ secretase (1). According to the amyloid cascade hypothesis (2), biochemical and genetic findings have suggested that $A \beta$ accumulation can induce tau phosphorylation and aggregation, synaptic dysfunction, and neuronal alteration, responsible for clinical signs of dementia (3). The precise mechanisms of neuronal demise have not been fully elucidated; however, apoptosis has been one of the most analyzed mechanisms in previous reports. Apoptosis is a sequence of events leading to the activation of caspases and cell disintegration. It has been proposed as the predominant form of cell death in $\mathrm{AD}$ due to unbalanced actions between pro and anti-apoptotic proteins $(4,5)$. Increased expression of several pro-apoptotic kinases has been observed in $\mathrm{AD}$ brains and their cellular pathways could be linked to $\mathrm{AD}$ physiopathology (6-13).

Protein kinases represent one of the largest super families, and they are molecular switches activating and inhibiting many biological processes, such as memory, differentiation, cell division, and cell death. They belong to complex metabolisms interacting with other kinases and their dysfunctions can be associated with various diseases (14). According to Hardy's hypothesis (3), A $\beta$ peptides can trigger protein kinases in $\mathrm{AD}$ participating in neuronal signaling pathways between $\mathrm{A} \beta$ 
and tau phosphorylation. Many of these kinases are also proapoptotic and could induce synaptic and neuronal sheddings.

Recently, reports have shown that cerebrospinal fluid (CSF) levels of $A \beta_{1-42}$, total tau (T-tau), and phosphorylated tau (ptau) were altered in $\mathrm{AD}$ patients and in patients with mild cognitive impairment (MCI) with higher risks to convert to $\mathrm{AD}$ (15). The analysis of CSF biomarkers has brought about new insights into the managing procedures of $\mathrm{AD}$ patients leading to new diagnostic criteria (16). The levels of these CSF biomarkers correlate with the severity of neuropathological lesions (17, 18). The use of CSF biomarkers has improved the confidence of clinicians for AD diagnosis (19) and now serves for the screening of patients in clinical trials (20). Because lumbar puncture (LP) is better known, more practiced, and well tolerated (21-24), physicians resort in CSF biomarkers more and more in clinical practice reflecting the impact on $\mathrm{AD}$ diagnosis $(25,26)$.

However, these classic CSF biomarkers are not directly predictive of the $\mathrm{AD}$ evolution. The need for new biomarkers remains to avoid the classification of patients by quintiles or clusters (27, 28). Furthermore, they have several pre-analytical requirements limiting the analysis to expert centers while $\mathrm{AD}$ patients are located everywhere in the world (29-31). Consequently, additional biomarkers are needed to predict the clinical evolution and cognitive decline, and to assess the efficiency of treatment targeting pathways of neuronal death.

This brief report will provide an overview of three proapoptotic protein kinases that are involved in $\mathrm{AD}$ physiopathology with detectable levels in biological fluids. We aim to address their place as new biomarkers reflecting the rate of neuronal death, predicting possibly the clinical evolution and requiring less preanalytical preparations.

\section{Pro-Apoptotic Kinases in Alzheimer's Disease}

\section{Double-Stranded RNA-Dependent Protein Kinase Involvement of PKR in AD Pathophysiology}

RNA-dependent protein kinase (PKR) is a serine/threonine proapoptotic kinase present in cells as non-activated. PKR plays a role in various cell functions (32) and is involved in apoptosis (33-40). Activation of PKR results from autophosphorylation on threonine residues 446 and 451 of the kinase domain (41-45). Once activated, PKR triggers several effectors and pathways leading to apoptosis including the activation of eukaryotic initiating factor 2 alpha $(e i F 2 \alpha)$, which inhibits protein synthesis. PKR participates in the activation of caspase 8 , which can contribute to the conversion of procaspase 3 into caspase $3(46,47)$. More widely, PKR activates both intrinsic and extrinsic apoptotic pathways (38, 48-51). Activated and pro-apoptotic forms of PKR (pPKR) can accumulate in several neurodegenerative diseases including $\mathrm{AD}$ $(9,12,52-54)$. In 2002, we have observed an abnormal activation of PKR in AD brains (9) and this result was confirmed by several teams $(12,52,53)$. Immunohistochemical findings performed in $\mathrm{AD}$ brains revealed an accumulation of pPKR around senile plaques (in dystrophic neurites), in the cytoplasm of neurons especially in the hippocampus and the temporal cortex, whereas neuronal staining was more nuclear in the frontal and parietal cortex $(8,55,56)$.

Using animal and cells models, we have shown that PKR is activated by $\mathrm{A} \beta$ peptide $(8,53,55-61)$ through its activator PACT (56), and this activation plays a role in neuronal death in $\mathrm{AD}(8$, $55,56)$, Furthermore, we have shown that the activation of PKR (partly by $\mathrm{A} \beta$ ) could control the levels of $\beta$-secretase (BACE1) in stressed cells. These data suggest the existence of a pathological self-sustaining loop involving PKR (1). On the other hand, we have reported a co-localization of ptau and pPKR (8). In neural cell cultures, $A \beta$ induced the phosphorylation of PKR, glycogen synthase kinase-3 $\beta$ (GSK-3 $\beta$ ), and tau. The pharmacological inhibition of PKR reduced GSK-3 activation and tau phosphorylation, suggesting that PKR could indirectly control the abnormal formation of tangles (8). Moreover, PKR has been shown to be implicated in memory (62). All these findings suggest that PKR plays a key role in the events leading to abnormal molecular signals at the origin of neurodegeneration in $\mathrm{AD}$.

\section{PKR as a New Biomarker}

The analysis of PKR levels in biological fluids of AD patients was further explored. In 2006, we observed increased pPKR levels in lymphocytes from $\mathrm{AD}$ patients compared to controls. However, an important overlap between the two groups was found showing that this biological test was not appropriate for diagnosis (63). The CSF is in direct contact with the brain and is less influenced by peripheral factors. We have evaluated CSF PKR concentrations in $\mathrm{AD}, \mathrm{MCI}$, and control individuals. Ninety one patients were included. The levels of total PKR (T-PKR), pPKR, A $\beta$, T-tau, and ptau were determined by Western blots or ELISA methods. The concentrations of T-PKR and pPKR were significantly increased in $\mathrm{AD}$ patients and in most MCI patients compared to neurological controls. The optimal threshold for pPKR to discriminate AD patients from controls gave a sensitivity of $91.1 \%$ and a specificity of $94.3 \%$. In the group of AD patients, concentrations of pPKR correlated with CSF levels of tau and ptau. A few AD or MCI patients with normal $A \beta$ and tau levels had increased pPKR levels. A correct discrimination between non-AD subjects and AD patients was possible with CSF PKR evaluations (11). To understand if pPKR and ptau could be found in extracellular fluid after the induction of neural endoplasmic reticulum (ER) stress, we have carried out a study in the supernatant of stressed human neuroblastoma cells. Results have revealed an increased concentration of T-PKR, pPKR, T-tau, and ptau after cellular stress. pPKR, together with tau, are released from neural cells due to an increased membrane permeability of unknown origin or late breakdown of the apoptotic plasma membrane. The fact that especially pPKR is increased in AD CSF (317\%) and much less T-PKR (38\%) could suggest that mainly pPKR accumulates in affected neurons before being released in the extracellular space of AD brains (11).

In a second step, we have analyzed in the same cohort, the predictive value of CSF pPKR levels on the cognitive decline over 2 years $(11,64)$. Every 6 months, patients underwent neurological exams and neuropsychological assessments including a Mini Mental State Examination (MMSE) evaluation. Using a multivariate linear mixed model, our results showed that the level of CSF 
pPKR was associated with a more pronounced cognitive decline. In this cohort, CSF pPKR levels were the only biomarkers linked to the cognitive decline over the follow-up survey. Furthermore, although classical biomarkers are very useful to predict the clinical outcome of MCI patients, the results of biomarker levels in the two groups of amnestic MCI patients (converters and non-converters) show that PKR was the most discriminant biomarker between the two groups (64).

\section{Glycogen Synthase Kinase-3 Protein Kinase GSK-3 $\beta$ and AD Pathophysiology}

Glycogen synthase kinase-3 (GSK-3) is a proline-directed serine/threonine kinase and is ubiquitously expressed with two isoforms, GSK-3 $\alpha$ and GSK-3 $\beta(65,66)$. GSK-3 has a role in many biological pathways including gene transcription, apoptosis (67), regulation of glycogen metabolism $(68,69)$, and microtubule stability $(70,71)$. GSK-3 $\beta$ is highly present in neurons (72) and can phosphorylate tau at 17 sites of the protein, more extensively than any other kinases (71). It is activated on two phosphorylation sites (Tyrosine 216 and Serine 9), which have opposite effects. Tyr216 phosphorylation leads to GSK-3 $\beta$ activation while serine 9 phosphorylation inhibits its activity (66). Evidences from several works have suggested that the involvement of GSK-3 in AD is linked to the reduction of acetylcholine synthesis (66) and to increased production of $A \beta$. GSK- $3 \beta$ can co-localize with ptau in dystrophic neurites and tangles $(8,73,74)$. Enhanced GSK-3 protein levels and activity were observed in the frontal cortex and hippocampus in AD brains (8). Furthermore, in 2012, we have shown that pPKR, activated GSK-3 $\beta$, and ptau proteins can be co-expressed in $\mathrm{AD}$ brains. In addition, PKR can modulate neuronal apoptosis and tau phosphorylation through GSK-3 $\beta$ activation. GSK-3 inhibition decreased tau phosphorylation without acting on PKR activation (8). It has recently been reported that a polymorphism in the GSK-3 promoter region is a risk factor for late onset AD (75). We have also shown that active $A \beta$ immunotherapy in $\mathrm{AD}$ patients induced a reduction of all GSK-3 $\beta$ forms; active, inactive, and total (76). Overall, the inactive GSK-3 $\beta$ appears to be the more abundant form compared to the active form. Finally, GSK-3 is proapoptotic and thereby might directly contribute to neuronal death in $\mathrm{AD}(67)$.

\section{GSK-3 as a Biomarker}

In 2004, Hye et al. explored GSK-3 levels in circulating lymphocytes. Total GSK- $3 \alpha$ and $\beta$ and inactive GSK-3 $\beta$ concentrations were assessed in white blood cells in a series of 113 patients including $\mathrm{AD}, \mathrm{MCI}$, and elderly controls. The results showed increased GSK-3 $\alpha(+65 \%)$ and GSK-3 $\beta(+59 \%)$ protein levels in AD and MCI compared to controls without concomitant augmentation of pGSK-3 $\beta$ (77).

In 2004, a decreased level of CSF GSK-3 $\beta$ in schizophrenic patients from a small cohort has been shown (78). The study did not evaluate activated or inactivated form of the kinase and so far no study has assessed CSF GSK-3 concentrations in AD patients.

Taking together, measurements of GSK-3 in biological fluids could be a supplemental biomarker reflecting $\mathrm{AD}$ pathology. Since GSK-3 is dramatically decreased in AD brains after active $A \beta$ immunization (76), CSF GSK-3 evaluation could reflect the efficiency of this therapeutic on neuronal stress and pro-apoptotic pathways.

\section{C-Jun N-Terminal Kinases JNK and AD Pathophysiology}

C-Jun N-terminal kinases (JNKs) are a family of serine/threonine protein kinases encoded by three genes (JNK1, JNK2, and JNK3). JNK1 and JNK2 are ubiquitous, and JNK3 is mainly expressed in the brain. JNKs are activated by phosphorylation (pJNK) through mitogen-activated protein (MAP) kinase kinase pathways induced by extracellular stimuli, such as cytokines and $A \beta$ peptides (79). JNKs have multiple functions, including regulation of gene expression, inflammation, cell proliferation, and apoptosis (80). In the brain, while JNK1 and 2 are involved in the development, JNK3 seems principally implicated in neurodegeneration (81). Previous studies have revealed that JNKs, particularly JNK3, can control BACE1 expression levels (82), can phosphorylate APP, and enhance $A \beta$ production $(83,84)$. The deletion of JNK3 has a neuroprotective effect against ischemia (85) and excitotoxicity $(86,87)$. A $\beta$-induced cell death is reduced in cultures of cortical neurons from JNK3 knockout (KO) mice, and JNKs have been implicated in experimental models of $\mathrm{AD}$ and Parkinson's disease. pJNK is increased in $\mathrm{AD}$ brains as well as upstream JNKs activators (88).

Immunohistochemical findings in $\mathrm{AD}$ brains have shown that the activated form of JNK ( $\mathrm{JJNK}$ ) was localized in peripheral rims of senile plaques, in neurofibrillary tangles, and granulovacuolar degenerations, as previously reported $(7,88)$. Neurons were modestly marked in the cytoplasm and in the nucleus in AD brains. In control brains, pJNK immunolabellings were rarely detected. The full form of JNK3 was detected, in the center and around senile plaques, as well as in the cytoplasm of neurons. Confocal imaging revealed an association between $\mathrm{A} \beta 42$ and JNK3 stainings in senile plaques, suggesting that JNK3 proteins may accumulate during the formation of amyloid aggregates (7). Immunochemical results revealed a significant correlation between $\mathrm{A} \beta$ and JNK3 levels in control and AD brains. In frontal cortex, pJNK and JNK3 could be detected in the same senile plaques. Quantification of these histological results showed an increase of JNK3 staining $(+59 \%)$ and pJNK staining $(+182 \%)$ in $\mathrm{AD}$ brains compared to control brains (7).

\section{JNK as a CSF Biomarker}

According to these results, JNK3 could be a marker of abnormal pathways in the CSF. In a recent study, CSF JNKs levels were evaluated by western blots in $\mathrm{AD}$ patients and neurological controls. JNK1, JNK2, and pJNK proteins were not detectable in the CSF. A significant increase of CSF JNK3 levels was found in AD patients compared to controls $(+23 \%)$. Optimal cut-offs showed that the JNK3 value of 70.3 optical density units (ODU) had a sensitivity of $80 \%$ and a specificity of $73 \%$, with an area under curve of 0.75 (7). No correlations were found between CSF JNK3 levels and age, sex, CSF levels of $A \beta_{1-42}$, T-tau, and pTau, as well as MRI evaluations using Fazekas scores (89) or Scheltens scales (90).

Patients with AD were followed for a mean period of $1.8( \pm 1.3)$ years. During the follow-up, clinicians performed $4.7( \pm 2.25)$ 
MMSE tests per patient. Using linear mixed models, a longitudinal analysis using tertiles of JNK3 levels was carried out. We found that patients in the third tertile ( $>89$ ODU) experienced a reduced and significant decline in MMSE scores over time. This association was maintained after adjusting for age, sex, educational levels, and MRI abnormalities. Comparison of the tertiles revealed that patients in the two lowest tertiles ( $<89$ ODU) experienced a more rapid decline of MMSE scores over time than those in the upper tertile (7).

\section{References}

1. Yan R, Vassar R. Targeting the beta secretase BACE1 for Alzheimer's disease therapy. Lancet Neurol (2014) 13:319-29. doi:10.1016/S1474-4422(13) 70276-X

2. Hardy JA, Higgins GA. Alzheimer's disease: the amyloid cascade hypothesis. Science (1992) 256:184-5. doi:10.1126/science.1566067

3. Hardy J. The amyloid hypothesis for Alzheimer's disease: a critical reappraisal. J Neurochem (2009) 110:1129-34. doi:10.1111/j.1471-4159.2009.06181.x

4. Lucassen PJ, Chung WC, Kamphorst W, Swaab DF. DNA damage distribution in the human brain as shown by in situ end labeling; area-specific differences in aging and Alzheimer disease in the absence of apoptotic morphology. J Neuropathol Exp Neurol (1997) 56:887-900. doi:10.1097/00005072-19970800000007

5. Friedlander RM. Apoptosis and caspases in neurodegenerative diseases. N Engl J Med (2003) 348:1365-75. doi:10.1056/NEJMra022366

6. Checler F, Alves da Costa C. p53 in neurodegenerative diseases and brain cancers. Pharmacol Ther (2014) 142:99-113. doi:10.1016/j.pharmthera.2013. 11.009

7. Gourmaud S, Paquet C, Dumurgier J, Pace C, Bouras C, Gray F, et al. Increased levels of cerebrospinal fluid JNK3 associated with amyloid pathology: links to cognitive decline. J Psychiatry Neurosci (2015) 40(3):151-61. doi:10.1503/jpn. 140062

8. Bose A, Mouton-Liger F, Paquet C, Mazot P, Vigny M, Gray F, et al. Modulation of tau phosphorylation by the kinase PKR: implications in Alzheimer's disease. Brain Pathol (2011) 21:189-200. doi:10.1111/j.1750-3639.2010.00437.x

9. Chang RC, Wong AK, Ng HK, Hugon J. Phosphorylation of eukaryotic initiation factor-2alpha (eIF2alpha) is associated with neuronal degeneration in Alzheimer's disease. Neuroreport (2002) 13:2429-32. doi:10.1097/00001756200212200-00011

10. Garcia MA, Gil J, Ventoso I, Guerra S, Domingo E, Rivas C, et al. Impact of protein kinase PKR in cell biology: from antiviral to antiproliferative action. Microbiol Mol Biol Rev (2006) 70:1032-60. doi:10.1128/MMBR.00027-06

11. Mouton-Liger F, Paquet C, Dumurgier J, Lapalus P, Gray F, Laplanche JL, et al. Increased cerebrospinal fluid levels of double-stranded RNA-dependant protein kinase in Alzheimer's disease. Biol Psychiatry (2012) 71:829-35. doi:10.1016/j. biopsych.2011.11.031

12. Peel AL, Bredesen DE. Activation of the cell stress kinase PKR in Alzheimer's disease and human amyloid precursor protein transgenic mice. Neurobiol Dis (2003) 14:52-62. doi:10.1016/S0969-9961(03)00086-X

13. Salloway S, Sperling R, Fox NC, Blennow K, Klunk W, Raskind M, et al. Two phase 3 trials of bapineuzumab in mild-to-moderate Alzheimer's disease. N Engl J Med (2014) 370:322-33. doi:10.1056/NEJMoa1304839

14. Shchemelinin I, Sefc L, Necas E. Protein kinases, their function and implication in cancer and other diseases. Folia Biol (2006) 52(3):81-100.

15. Blennow K, Hampel H, Weiner M, Zetterberg H. Cerebrospinal fluid and plasma biomarkers in Alzheimer disease. Nat Rev Neurol (2010) 6:131-44. doi:10.1038/nrneurol.2010.4

16. McKhann GM, Knopman DS, Chertkow H, Hyman BT, Jack CR Jr, Kawas $\mathrm{CH}$, et al. The diagnosis of dementia due to Alzheimer's disease: recommendations from the national institute on aging-Alzheimer's association workgroups on diagnostic guidelines for Alzheimer's disease. Alzheimers Dement (2011) 7:263-9. doi:10.1016/j.jalz.2011.03.005

17. Tapiola T, Alafuzoff I, Herukka SK, Parkkinen L, Hartikainen P, Soininen H, et al. Cerebrospinal fluid \{beta\}-amyloid 42 and tau proteins as biomarkers of

\section{Conclusion}

Apoptosis seems an important way of cellular death in AD. Several pro-apoptotic kinases are involved in the pathophysiology of $\mathrm{AD}$, and the evaluations of CSF concentrations could be useful to predict the cognitive decline. In addition, since these three kinases are implicated in neuronal apoptosis, they represent new therapeutic targets that could afford neuroprotection and alter the relentless clinical evolution in $\mathrm{AD}$ patients.

Alzheimer-type pathologic changes in the brain. Arch Neurol (2009) 66:382-9. doi:10.1001/archneurol.2008.596

18. Jagust WJ, Landau SM, Shaw LM, Trojanowski JQ, Koeppe RA, Reiman EM, et al. Relationships between biomarkers in aging and dementia. Neurology (2009) 73:1193-9. doi:10.1212/WNL.0b013e3181bc010c

19. Mouton-Liger F, Wallon D, Troussiere AC, Yatimi R, Dumurgier J, Magnin E, et al. Impact of cerebro-spinal fluid biomarkers of Alzheimer's disease in clinical practice: a multicentric study. J Neurol (2014) 261:144-51. doi:10.1007/s00415013-7160-3

20. Dumurgier J, Laplanche JL, Mouton-Liger F, Lapalus P, Indart S, Prevot M, et al. The screening of Alzheimer's patients with CSF biomarkers, modulates the distribution of APOE genotype: impact on clinical trials. J Neurol (2014) 261:1187-95. doi:10.1007/s00415-014-7335-6

21. Paquet C, Latour F, Saulnier I, Hanon O. [Multicenter study on lumbar puncture indication, clinical practice and feasibility]. Rev Neurol (Paris) (2012) 168:28-32. doi:10.1016/j.neurol.2011.08.012

22. Heitz C, Lorette A, Julian A, Roubaud C, Paquet C. [Lumbar puncture practice in case of hemorrhagic or ischemic risk: a national opinion survey]. Rev Neurol (2014) 170:685-92. doi:10.1016/j.neurol.2014.05.007

23. Peskind E, Nordberg A, Darreh-Shori T, Soininen H. Safety of lumbar puncture procedures in patients with Alzheimer's disease. Curr Alzheimer Res (2009) 6:290-2. doi:10.2174/156720509788486509

24. Zetterberg H, Tullhog K, Hansson O, Minthon L, Londos E, Blennow K. Low incidence of post-lumbar puncture headache in 1,089 consecutive memory clinic patients. Eur Neurol (2010) 63:326-30. doi:10.1159/000311703

25. Schoonenboom NS, Reesink FE, Verwey NA, Kester MI, Teunissen CE, van de Ven PM, et al. Cerebrospinal fluid markers for differential dementia diagnosis in a large memory clinic cohort. Neurology (2012) 78:47-54. doi:10.1212/WNL. ob013e31823ed0f0

26. Troussiere AC, Wallon D, Mouton-Liger F, Yatimi R, Robert P, Hugon J, et al. Who needs cerebrospinal biomarkers? A national survey in clinical practice. $J$ Alzheimers Dis (2014) 40:857-61. doi:10.3233/JAD- 132672

27. Wallin AK, Blennow K, Zetterberg H, Londos E, Minthon L, Hansson O. CSF biomarkers predict a more malignant outcome in Alzheimer disease. Neurology (2010) 74:1531-7. doi:10.1212/WNL.0b013e3181dd4dd8

28. Kester MI, van der Vlies AE, Blankenstein MA, Pijnenburg YA, van Elk EJ, Scheltens $\mathrm{P}$, et al. CSF biomarkers predict rate of cognitive decline in Alzheimer disease. Neurology (2009) 73:1353-8. doi:10.1212/WNL. 0b013e3181bd8271

29. Dumurgier J, Vercruysse O, Paquet C, Bombois S, Chaulet C, Laplanche JL, et al. Intersite variability of CSF Alzheimer's disease biomarkers in clinical setting. Alzheimers Dement (2013) 9:406-13. doi:10.1016/j.jalz.2012.06.006

30. Gabelle A, Dumurgier J, Vercruysse O, Paquet C, Bombois S, Laplanche JL, et al. Impact of the 2008-2012 French Alzheimer plan on the use of cerebrospinal fluid biomarkers in research memory center: the PLM study. J Alzheimers Dis (2013) 34:297-305. doi:10.3233/JAD- 121549

31. Lehmann S, Schraen S, Quadrio I, Paquet C, Bombois S, Delaby C, et al. Impact of harmonization of collection tubes on Alzheimer's disease diagnosis. Alzheimers Dement (2014) 10(5 Suppl):S390-4.e2. doi:10.1016/j.jalz.2013. 06.008

32. Proud CG. PKR: a new name and new roles. Trends Biochem Sci (1995) 20:241-6. doi:10.1016/S0968-0004(00)89025-8

33. Lee SB, Esteban M. The interferon-induced double-stranded RNA-activated protein kinase induces apoptosis. Virology (1994) 199:491-6. doi:10.1006/viro. 1994.1151 
34. Castelli JC, Hassel BA, Maran A, Paranjape J, Hewitt JA, Li XL, et al. The role of 2'-5' oligoadenylate-activated ribonuclease L in apoptosis. Cell Death Differ (1998) 5:313-20. doi:10.1038/sj.cdd.4400352

35. Cotman CW, Su JH. Mechanisms of neuronal death in Alzheimer's disease. Brain Pathol (1996) 6:493-506. doi:10.1111/j.1750-3639.1996.tb00878.x

36. Der SD, Yang YL, Weissmann C, Williams BR, double-stranded A. RNAactivated protein kinase-dependent pathway mediating stress-induced apoptosis. Proc Natl Acad Sci U S A (1997) 94:3279-83. doi:10.1073/pnas.94.7.3279

37. Kibler KV, Shors T, Perkins KB, Zeman CC, Banaszak MP, Biesterfeldt J, et al. Double-stranded RNA is a trigger for apoptosis in vaccinia virus-infected cells. J Virol (1997) 71:1992-2003.

38. Srivastava SP, Kumar KU, Kaufman RJ. Phosphorylation of eukaryotic translation initiation factor 2 mediates apoptosis in response to activation of the double-stranded RNA-dependent protein kinase. J Biol Chem (1998) 273:2416-23. doi:10.1074/jbc.273.4.2416

39. Takizawa T, Ohashi K, Nakanishi Y. Possible involvement of double-stranded RNA-activated protein kinase in cell death by influenza virus infection. J Virol (1996) 70:8128-32.

40. Yeung MC, Chang DL, Camantigue RE, Lau AS. Inhibitory role of the host apoptogenic gene PKR in the establishment of persistent infection by encephalomyocarditis virus in U937 cells. Proc Natl Acad Sci U S A (1999) 96:11860-5. doi:10.1073/pnas.96.21.11860

41. Carpick BW, Graziano V, Schneider D, Maitra RK, Lee X, Williams BR. Characterization of the solution complex between the interferon-induced, doublestranded RNA-activated protein kinase and HIV-I trans-activating region RNA. J Biol Chem (1997) 272:9510-6. doi:10.1074/jbc.272.14.9510

42. Dey M, Cao C, Dar AC, Tamura T, Ozato K, Sicheri F, et al. Mechanistic link between PKR dimerization, autophosphorylation, and eIF2alpha substrate recognition. Cell (2005) 122:901-13. doi:10.1016/j.cell.2005.06.041

43. Galabru J, Hovanessian A. Autophosphorylation of the protein kinase dependent on double-stranded RNA. J Biol Chem (1987) 262:15538-44.

44. Hovanessian AG. The double stranded RNA-activated protein kinase induced by interferon: dsRNA-PK. J Interferon Res (1989) 9:641-7. doi:10.1089/jir.1989. 9.641

45. Zhang F, Romano PR, Nagamura-Inoue T, Tian B, Dever TE, Mathews MB, et al. Binding of double-stranded RNA to protein kinase PKR is required for dimerization and promotes critical autophosphorylation events in the activation loop. J Biol Chem (2001) 276:24946-58. doi:10.1074/jbc.M102108200

46. Balachandran S, Kim CN, Yeh WC, Mak TW, Bhalla K, Barber GN. Activation of the dsRNA-dependent protein kinase, PKR, induces apoptosis through FADD-mediated death signaling. EMBO J (1998) 17:6888-902. doi:10.1093/ emboj/17.23.6888

47. Gil J, Esteban M. The interferon-induced protein kinase (PKR), triggers apoptosis through FADD-mediated activation of caspase 8 in a manner independent of Fas and TNF-alpha receptors. Oncogene (2000) 19:3665-74. doi:10.1038/sj. onc. 1203710

48. Clemens MJ, Hershey JW, Hovanessian AC, Jacobs BC, Katze MG, Kaufman RJ, et al. PKR: proposed nomenclature for the RNA-dependent protein kinase induced by interferon. J Interferon Res (1993) 13:241. doi:10.1089/jir. 1993.13.241

49. Donze O, Deng J, Curran J, Sladek R, Picard D, Sonenberg N. The protein kinase PKR: a molecular clock that sequentially activates survival and death programs. EMBO J (2004) 23:564-71. doi:10.1038/sj.emboj.7600078

50. Gil J, Alcami J, Esteban M. Induction of apoptosis by double-strandedRNA-dependent protein kinase (PKR) involves the alpha subunit of eukaryotic translation initiation factor 2 and NF-kappaB. Mol Cell Biol (1999) 19: 4653-63.

51. Scheuner D, Patel R, Wang F, Lee K, Kumar K, Wu J, et al. Doublestranded RNA-dependent protein kinase phosphorylation of the alpha-subunit of eukaryotic translation initiation factor 2 mediates apoptosis. J Biol Chem (2006) 281:21458-68. doi:10.1074/jbc.M603784200

52. Bando Y, Onuki R, Katayama T, Manabe T, Kudo T, Taira K, et al. Doublestrand RNA dependent protein kinase (PKR) is involved in the extrastriatal degeneration in Parkinson's disease and Huntington's disease. Neurochem Int (2005) 46:11-8. doi:10.1016/j.neuint.2004.07.005

53. Onuki R, Bando Y, Suyama E, Katayama T, Kawasaki H, Baba T, et al. An RNA-dependent protein kinase is involved in tunicamycin-induced apoptosis and Alzheimer's disease. EMBO J (2004) 23:959-68. doi:10.1038/sj.emboj. 7600049
54. Hu JH, Zhang H, Wagey R, Krieger C, Pelech SL. Protein kinase and protein phosphatase expression in amyotrophic lateral sclerosis spinal cord. J Neurochem (2003) 85:432-42. doi:10.1046/j.1471-4159.2003.01670.x

55. Mouton-Liger F, Paquet C, Dumurgier J, Bouras C, Pradier L, Gray F, et al. Oxidative stress increases BACE1 protein levels through activation of the PKReIF2alpha pathway. Biochim Biophys Acta (2012) 1822:885-96. doi:10.1016/j. bbadis.2012.01.009

56. Paquet C, Mouton-Liger F, Meurs EF, Mazot P, Bouras C, Pradier L, et al. The PKR activator PACT is induced by Abeta: involvement in Alzheimer's disease. Brain Pathol (2012) 22:219-29. doi:10.1111/j.1750-3639.2011.00520.x

57. Ito M, Onuki R, Bando Y, Tohyama M, Sugiyama Y. Phosphorylated PKR contributes the induction of GRP94 under ER stress. Biochem Biophys Res Commun (2007) 360:615-20. doi:10.1016/j.bbrc.2007.06.087

58. Mecha M, Torrao AS, Mestre L, Carrillo-Salinas FJ, Mechoulam R, Guaza C. Cannabidiol protects oligodendrocyte progenitor cells from inflammationinduced apoptosis by attenuating endoplasmic reticulum stress. Cell Death Dis (2012) 3:e331. doi:10.1038/cddis.2012.71

59. Shimazawa M, Ito $\mathrm{Y}$, Inokuchi $\mathrm{Y}$, Hara $\mathrm{H}$. Involvement of double-stranded RNA-dependent protein kinase in ER stress-induced retinal neuron damage. Invest Ophthalmol Vis Sci (2007) 48:3729-36. doi:10.1167/iovs.06-1122

60. Singh M, Fowlkes V, Handy I, Patel CV, Patel RC. Essential role of PACTmediated PKR activation in tunicamycin-induced apoptosis. J Mol Biol (2009) 385:457-68. doi:10.1016/j.jmb.2008.10.068

61. Vaughn LS, Snee B, Patel RC. Inhibition of PKR protects against tunicamycininduced apoptosis in neuroblastoma cells. Gene (2014) 536:90-6. doi:10.1016/ j.gene.2013.11.074

62. Zhu PJ, Huang W, Kalikulov D, Yoo JW, Placzek AN, Stoica L, et al. Suppression of PKR promotes network excitability and enhanced cognition by interferongamma-mediated disinhibition. Cell (2011) 147:1384-96. doi:10.1016/j.cell. 2011.11.029

63. Paccalin M, Pain-Barc S, Pluchon C, Paul C, Besson MN, Carret-Rebillat AS, et al. Activated mTOR and PKR kinases in lymphocytes correlate with memory and cognitive decline in Alzheimer's disease. Dement Geriatr Cogn Disord (2006) 22:320-6. doi:10.1159/000095562

64. Dumurgier J, Mouton-Liger F, Lapalus P, Prevot M, Laplanche JL, Hugon J, et al. Cerebrospinal fluid PKR level predicts cognitive decline in Alzheimer's disease. PLoS One (2013) 8:e53587. doi:10.1371/journal.pone.0053587

65 . Woodgett JR. Molecular cloning and expression of glycogen synthase kinase3/factor A. EMBO J (1990) 9:2431-8.

66. Hooper C, Killick R, Lovestone S. The GSK3 hypothesis of Alzheimer's disease. J Neurochem (2008) 104:1433-9. doi:10.1111/j.1471-4159.2007.05194.x

67. Beurel E, Jope RS. The paradoxical pro- and anti-apoptotic actions of GSK3 in the intrinsic and extrinsic apoptosis signaling pathways. Prog Neurobiol (2006) 79:173-89. doi:10.1016/j.pneurobio.2006.07.006

68. Embi N, Rylatt DB, Cohen P. Glycogen synthase kinase-3 from rabbit skeletal muscle. Separation from cyclic-AMP-dependent protein kinase and phosphorylase kinase. Eur J Biochem (1980) 107:519-27. doi:10.1111/j.1432-1033.1980. tb06059.x

69. Woodgett JR, Cohen P. Multisite phosphorylation of glycogen synthase. Molecular basis for the substrate specificity of glycogen synthase kinase- 3 and casein kinase-II (glycogen synthase kinase-5). Biochim Biophys Acta (1984) 788:339-47. doi:10.1016/0167-4838(84)90047-5

70. Anderton BH, Betts J, Blackstock WP, Brion JP, Chapman S, Connell J, et al. Sites of phosphorylation in tau and factors affecting their regulation. Biochem Soc Symp (2001) 67:73-80.

71. Brion JP, Anderton BH, Authelet M, Dayanandan R, Leroy K, Lovestone S, et al. Neurofibrillary tangles and tau phosphorylation. Biochem Soc Symp (2001) 67:81-8.

72. Leroy K, Boutajangout A, Authelet M, Woodgett JR, Anderton BH, Brion JP. The active form of glycogen synthase kinase-3beta is associated with granulovacuolar degeneration in neurons in Alzheimer's disease. Acta Neuropathol (2002) 103:91-9. doi:10.1007/s004010100435

73. Pei JJ, Braak E, Braak H, Grundke-Iqbal I, Iqbal K, Winblad B, et al. Distribution of active glycogen synthase kinase 3beta (GSK-3beta) in brains staged for Alzheimer disease neurofibrillary changes. J Neuropathol Exp Neurol (1999) 58:1010-9. doi:10.1097/00005072-199909000-00011

74. Elyaman W, Yardin C, Hugon J. Involvement of glycogen synthase kinase-3beta and tau phosphorylation in neuronal Golgi disassembly. J Neurochem (2002) 81:870-80. doi:10.1046/j.1471-4159.2002.00838.x 
75. Mateo I, Vazquez-Higuera JL, Sanchez-Juan P, Rodriguez-Rodriguez E, Infante J, Garcia-Gorostiaga I, et al. Epistasis between tau phosphorylation regulating genes (CDK5R1 and GSK-3beta) and Alzheimer's disease risk. Acta Neurol Scand (2009) 120:130-3. doi:10.1111/j.1600-0404.2008.01128.x

76. Amin J, Paquet C, Baker A, Asuni AA, Love S, Holmes C, et al. Effect of Abeta immunisation on hyperphosphorylated tau: a potential role for GSK-3beta. Neuropathol Appl Neurobiol (2015) 41(4):445-57. doi:10.1111/nan.12205

77. Hye A, Kerr F, Archer N, Foy C, Poppe M, Brown R, et al. Glycogen synthase kinase-3 is increased in white cells early in Alzheimer's disease. Neurosci Lett (2005) 373:1-4. doi:10.1016/j.neulet.2004.10.031

78. Kozlovsky N, Regenold WT, Levine J, Rapoport A, Belmaker RH, Agam G. GSK-3beta in cerebrospinal fluid of schizophrenia patients. J Neural Transm (2004) 111:1093-8. doi:10.1007/s00702-003-0127-0

79. Daher A, Laraki G, Singh M, Melendez-Pena CE, Bannwarth S, Peters AH, et al. TRBP control of PACT-induced phosphorylation of protein kinase $\mathrm{R}$ is reversed by stress. Mol Cell Biol (2009) 29:254-65. doi:10.1128/MCB.01030-08

80. Wei W, Norton DD, Wang X, Kusiak JW. Abeta 17-42 in Alzheimer's disease activates JNK and caspase-8 leading to neuronal apoptosis. Brain (2002) 125:2036-43. doi:10.1093/brain/awf205

81. Bogoyevitch MA. The isoform-specific functions of the c-Jun N-terminal Kinases (JNKs): differences revealed by gene targeting. Bioessays (2006) 28:923-34. doi:10.1002/bies.20458

82. Tamagno E, Guglielmotto M, Aragno M, Borghi R, Autelli R, Giliberto L, et al. Oxidative stress activates a positive feedback between the gamma- and betasecretase cleavages of the beta-amyloid precursor protein. J Neurochem (2008) 104(3):683-95. doi:10.1111/j.1471-4159.2007.05072.x

83. Colombo A, Bastone A, Ploia C, Sclip A, Salmona M, Forloni G, et al. JNK regulates APP cleavage and degradation in a model of Alzheimer's disease. Neurobiol Dis (2009) 33:518-25. doi:10.1016/j.nbd.2008.12.014

84. Yoon SO, Park DJ, Ryu JC, Ozer HG, Tep C, Shin YJ, et al. JNK3 perpetuates metabolic stress induced by Abeta peptides. Neuron (2012) 75:824-37. doi:10. 1016/j.neuron.2012.06.024

85. Kuan CY, Whitmarsh AJ, Yang DD, Liao G, Schloemer AJ, Dong C, et al. A critical role of neural-specific JNK3 for ischemic apoptosis. Proc Natl Acad Sci U S A (2003) 100:15184-9. doi:10.1073/pnas.2336254100
86. Brecht S, Kirchhof R, Chromik A, Willesen M, Nicolaus T, Raivich G, et al. Specific pathophysiological functions of JNK isoforms in the brain. Eur J Neurosci (2005) 21:363-77. doi:10.1111/j.1460-9568.2005.03857.x

87. Yang DD, Kuan CY, Whitmarsh AJ, Rincon M, Zheng TS, Davis RJ, et al. Absence of excitotoxicity-induced apoptosis in the hippocampus of mice lacking the Jnk3 gene. Nature (1997) 389:865-70. doi:10.1038/38154

88. Zhu X, Raina AK, Rottkamp CA, Aliev G, Perry G, Boux H, et al. Activation and redistribution of c-jun N-terminal kinase/stress activated protein kinase in degenerating neurons in Alzheimer's disease. J Neurochem (2001) 76:435-41. doi:10.1046/j.1471-4159.2001.00046.x

89. Fazekas F, Chawluk JB, Alavi A, Hurtig HI, Zimmerman RA. MR signal abnormalities at $1.5 \mathrm{~T}$ in Alzheimer's dementia and normal aging. AJR Am J Roentgenol (1987) 149:351-6. doi:10.2214/ajr.149.2.351

90. Scheltens P, Leys D, Barkhof F, Huglo D, Weinstein HC, Vermersch P, et al. Atrophy of medial temporal lobes on MRI in "probable" Alzheimer's disease and normal ageing: diagnostic value and neuropsychological correlates. J Neurol Neurosurg Psychiatry (1992) 55:967-72. doi:10.1136/jnnp.55.10.967

Conflict of Interest Statement: Claire Paquet, Julien Dumurgier, and Jacques Hugon are investigators in $A \beta$ immunotherapy trials for Lilly and Eisai. Jacques Hugon is a consultant for Roche in relation to $A \beta$ immunotherapy trials. In our part, studies on PKR were funded by French Alzheimer Plan, studies on GSK-3 $\beta$ were funded by NEURAD (Marie Curie funding), studies on JNK received University and INSERM funding. The funders had no role in study design, data collection and analysis, decision to publish, or preparation of the manuscript. Patent and license: CSF PKR levels received a world patented and license « Méthodes de diagnostic des maladies neurodégénératives »(BE11754519.4 PCT/IB2011/053571).

Copyright (C) 2015 Paquet, Dumurgier and Hugon. This is an open-access article distributed under the terms of the Creative Commons Attribution License (CC BY). The use, distribution or reproduction in other forums is permitted, provided the original author(s) or licensor are credited and that the original publication in this journal is cited, in accordance with accepted academic practice. No use, distribution or reproduction is permitted which does not comply with these terms. 